\title{
BRAND POWER: A Study On New Product Development Strategy In Bathing Soap In Special Reference To Chennai City
}

\author{
R.Murugan \\ Research Scholar \\ Department of management studies \\ Anna university, Chennai \\ Dr.K.Narashiman \\ Professor \\ Department of Chemical engineering \\ Anna University. Chennai
}

\begin{abstract}
The Importance of New Product Development in a country is increasing day by day for providing product with punctuality at affordable price and always has to maintain superior quality according to buyer's requirement. The relevance of product innovations and new product development is done for the competitive advantage of the firm and for the long-term economic growth. The study focuses on the development of a new product, which the company plan to launch on the bathing soap market. By presenting a report, this paper aims to highlight the strengths and weaknesses of the new product development process undertaken by the company. The soap industry experienced an unprecedented rate of increase in the cost of developing new bathing soap while the number of new drugs that were approved and accepted in the marketplace has reached a very low level.
\end{abstract}

\section{Introduction \\ Marketing}

The term marketing has changed and evolved over a period, today marketing is based around providing continual benefits to the customer, these benefits will be provided and a transactional exchange will take place.

As defined by the Chartered Institute of Marketing, "Marketing is the management process that identifies, anticipates and satisfies customer requirements profitably". It can also be defined as 'Marketing is the human activity directed at satisfying human needs and wants through an exchange process" as defined by Kotler. "Marketing is a social and managerial process by which individuals and groups obtain what they want and need through creating, offering and exchanging products of value with others" Kotler 1991.

\subsection{NEW PRODUCT DEVELOPMENT}

Product development means making changes in the size, design, colour, shape, characteristics, packing etc. of the product. It may include addition of a new product line, addition of a new product item in a particular product line, elimination of existing product or product line \& changes in the size, colour, design, packing, characteristics, and prices of the product \& discontinuation of the unprofitable item or product line. A new product is any product which is perceived by the customer as being new.

\subsection{REASONS FOR NEW PRODUCTS:}

There are at least 3 reasons for which new products should be developed.

$\begin{array}{ll}\checkmark & \text { New products become necessary for meeting } \\ & \text { changes in consumer needs. } \\ & \text { New products become necessary for making } \\ & \text { profits. } \\ & \text { New products become necessary for comb } \\ \text { environmental threats. } & \\ \text { 1.3 CATEGORIES OF NEW PRODUCTS: } \\ \text { 1: } & \text { New to the world. } \\ \text { 2: } & \text { New to the product lines. } \\ \text { 3: } & \text { Additions to the existing product line. } \\ \text { 4: } & \text { Improvements \& revisions of existing products. } \\ \text { 5: } & \text { Repositioning. } \\ \text { 6: } & \text { Cost reductions. }\end{array}$

\subsection{FACTORS OF NEW PRODUCT DEVELOPMENT:}

New product development is a continuous function of marketing management in the present day highly competitive environment. In the process of new product development, a company should keep in mind the following considerations: Adequate market demand. The product should fit into company's present market structure. The idea should fit into the company's present production structure. The product should fit as per the financial resources available. Adequate distribution in depth \& breadth.

\subsubsection{NEW PRODUCT DEVELOPMENT PROCESS:} STEP 1: IDEA GENERATION:

The new product development process starts with the search 
for ideas. Consumer's problems are the most fertile ground for the generation of new product ideas. New product ideas come from interacting with various groups \& from using creativity generation techniques like BRAINSTORMING, SYNECTICS etc. BRAINSTORMING is a process, where a small group of people are encouraged to come up with their ideas on a specified problem. Whereas in SYNECTICS, the real problem is kept away initially from the group \& only a broader framework of the problem is given to them. The group is encouraged to think in all possible dimensions and slowly the problem will be made clear to them, $\&$ their ideas would get refined.

\section{STEP 2: IDEA SCREENING:}

The purpose of screening stage is to drop poor ideas as early as possible. Thus an idea committee is formed to classify the proposed ideas into 3 categories, such as: promising, marginal $\&$ rejects. Every promising idea is kept together for rigorous screening by product evaluation committee. In screening ideas, the companies normally face 2 serious errors \& they must try to avoid these mistakes as far as possible, those 2 serious errors are: DROP ERROR \& GO ERROR. Let's clarify: DROP ERROR: error which occurs when the company rejects one really good idea having potential. GO ERROR: error which occurs, when the company permits \& facilitates a poor idea to move onto further development stages \& commercialization.

\section{STEP 3: CONCEPT DEVELOPMENT \& TESTING:}

A concept is an elaborated version of a product idea expressed in meaningful consumer terms. After the product concept has been developed, the stage is now set for testing them. It is here the prospective consumer understand the product idea. Here whether they are receptive towards the idea \& their willingness to try out such product is tested.

\section{STEP 4: BUSINESS ANALYSIS:}

This stage will decide whether from financial as well as marketing point of view, the project is beneficial or not. The projects overall impact on the corporation's financial position with \& without the new product are estimated \& compared. Here management needs to prepare sales as well as cost \& profit projections to determine whether they satisfy company objectives.

\section{STEP 5: PROTOTYPING \& MARKET TESTING:}

At this stage the company will determine whether the product idea can be translated into technically \& commercially feasible product. Its goal is to find a prototype that consists the key attributes described in the product concept \& that performs safely under normal use \& conditions and that can be produced within the budgeted cost. Here the companies conduct 2 types of major testing's, such as: ALPHA TESTING \& BETA TESTING. ALPHA TESTING: testing within the firm to see its function.

BETA TESTING: BETA testing includes listing of a set of customers to use the prototype and ask their feedback.

MARKET TESTING: The product here is actually tested in the selected market segments. Based on the outcomes of the test marketing, the marketer lunches large scale manufacture of the new product. It is a controlled marketing experiment to decide the soundness \& feasibility of fully fledged marketing of the product.

\section{STEP 6: TECHNOLOGICAL IMPLEMANTATION:}

It involves technical feasibility, search for new available technologies \& its economic alternatives if available. It also includes the technological relevance of current technologies, the firm's knowledge \& experience of the techniques, manpower in handling those technologies etc.

\section{STEP 7: COMMERCIALISATION:}

At this stage the company takes decision to go in for large scale production \& marketing of the new product. Various marketing strategies are employed by the company at this stage, when it starts commercialization of a new product idea. The important factors to which strategists should focus here are: Market entry timing period refers to whether to lunch the product in a single locality, a region, several regions, nationally or internationally, i.e. geographic strategy. To whom the new product should target for i.e. targeting \& segmenting.

\section{INDUSTRY PROFILE \\ 2.1 THE ORIGIN OF SOAP}

Although no one really knows when soap was discovered, there are various legends surrounding it's beginning. According to Roman legend, soap was named after Mount Sapo, an ancient site of animal sacrifices. After an animal sacrifice, rain would wash animal fat and ash that collected under the ceremonial altars down to the banks of the Tiber River.

Women washing clothes in the river noticed that if they washed their clothes in certain parts of the river after a heavy rain their clothes were much cleaner. Thus the emergence of the first soap - or at least the first use of soap.

A soap-like material found in clay cylinders during the excavation of ancient Babylon is evidence that soap making was known as early as 2800 B.C. Inscriptions on the cylinders say that fats were boiled with ashes, a soap-making method.

Moses gave the Israelites detailed laws governing personal cleanliness. Biblical accounts suggest that the Israelites knew that mixing ashes and oil produced a kind of hair gel. Soap is mentioned twice in the Bible, but it is generally agreed that the Hebrew word "borith", which has been translated as soap, is a generic term for any cleansing agent.

By the second century A.D., the Greek physician, Galen, recommended soap for both medicinal and cleansing purposes.

Bathing habits all over Europe rose and declined with Roman civilization. When Rome fell in 467 A.D., so did bathing. It's said that the lack of cleanliness and poor living conditions contributed to the many plagues of the Middle Ages.

Not until the seventh century did soapmakers appear in Spain and Italy where soap was made with goat fat and Beech tree ashes. During the same period, the French started using olive oil to make soap. Eventually, fragrances were introduced and specialized soaps for bathing, shaving, shampooing, and laundry began to appear. King Louis XIV of France 
apparently guillotined three soapmakers for making a bar that irritated his very sensitive Royal skin.

The English began making soap during the 12th century. In 1633 King Charles I granted a 14 year monopoly to the Society of Soap makers of Westminster. In the reign of Elizabeth I, soap consumption in England was greater than in any other European country. It seems that Queen Bess set the fashion herself, for it was reported that the Queen took a bath every four weeks "whether it was necessary or not." Just as the soap industry was gaining momentum in England, it became the subject of a series of restrictions and crippling taxation. It was not until 1853 that Gladstone abolished the tax on soap.

It wasn't until the 18th century that bathing came into fashion. In 1791, the French chemist Nicolas Leblanc discovered how to extract soda from common salt. Around the same time, Louis Pasteur proclaimed that good personal hygiene would reduce the spread of diseases.

By the beginning of the 19th century, soap making was one of the fastest growing industries in the U.S. Rural Americans made homemade soap using a process from the Colonial times. They would save ashes from their fires for months. When they had enough fat left over from butchering hogs they would make soap.

Some soapmakers used an ash hopper for making lye instead of the barrel method. Using the same basic process, the lye dripped into a container located underneath the hopper.

The most difficult part of early soapmaking was determining if the lye was the correct strength. The "lye water" was considered the proper strength to make soap when an egg or small potato placed in the solution floated about halfway beneath the surface of the solution. If the egg or potato floated on top, the lye was too strong. If it sank quickly, the lye was too weak. Some early soapmakers used goose or chicken feathers to test their lye. If a feather inserted in the lye water began to dissolve in it, then the lye water was at the right strength.

During World War I, commercial soap, as we know it today, came into existence. The injuries of war brought an increased need for cleaning agents. However, at the same time, the ingredients needed to make soap were scarce. German scientists created a new form of "soap" made with various synthetic compounds and as a result detergents were born. Most commercial soaps available today are actually detergents, which are made with petroleum by-products. Since these "soaps" are detergents, by law cannot be called soap. Chances are that when you see a soap called a "body cleanser", it is not soap at all.

After the Great War and until the 1930's, soap was made by a method called batch kettle boiling. Commercial soap makers had huge three story kettles that produced thousands of pounds of soap over the course of about a week. Shortly thereafter, an invention called continuous process was introduced and refined by Procter \& Gamble. This process decreased soap making production time to less than a day. Large commercial soap manufacturers still use continuous process.

Today there is a heightened awareness of the possible adverse effects of many of the synthetic additives and chemicals in commercial soap. Educated consumers are turning to all natural products like ours. Even large companies are starting to advertise "natural ingredients" in their products. BUT BEWARE! The addition of one or two natural ingredients does not make a product "all natural." It is virtually impossible for large companies to create natural, handmade soaps.

\section{RESEARCH PROBLEM}

In this report we are making a study the impact on brand power in a new product development strategies of bathing soap industry in order to analyse various factors that contribute to a successful new product development. We also understand the distribution channels followed by the company.

So as to study the "new product development strategies" we divide the problem into various parts, so that it can be easily solved.

\subsection{OBJECTIVES}

- To identify the customer perception towards in a impact on new product development bathing soap in Chennai

- To measure the various sources of promotional inputs used for branded bathing soap

\subsection{METHODOLOGY:}

Research methodology is a way of systematically solving the research problem. Research methodology deals with the research design used and methods used to present the study.

\subsection{RESERACH DESIGN:}

A research design is a detailed blue print used to guide a research study towards its objective. The process of designing a research study involves many interrelated decisions. The most significant is the choice of research approach, because it determines how the information will be obtained. The choice of the research approach depends on the nature of the research that one wants to do.

\subsection{DESCRIPTIVE METHOD}

The research design adopted for this study is descriptive research. Descriptive method was adopted because it deals with description of the state of affairs as it exists at present.

The next step in research study after collecting data is the sampling process. When a decision is made to use the sample, a number of factors must be taken into consideration. The various steps involved in the sampling processes are:

- Identifying target population.

- $\quad$ Determining sample frame.

- $\quad$ Selecting sampling procedure.

- Determining sample size.

- $\quad$ Execute sampling.

- Obtaining information from the respondents.

- Generating information for decision making.

\subsection{CONVENIENT SAMPLING}

It is a sampling method in which units are selected based on easy availability.

The disadvantage of convenience sampling is that the units 
that are easiest to obtain may not be representative of the population. It is also called as accidental sampling.

A convenience sample is a sample of study subjects taken from a group which is conveniently accessible to researcher. The advantage of a convenience sample is that it is easy to access, requiring little effort on the part of the researcher. The disadvantage is that it is not an accurate representation of the population, which can skew the results quite radically. In fact, convenience is regarded as a form of sampling bias, meaning that the results from a study conducted with such a sample cannot be generalized to the population as a whole.

\subsection{SAMPLE SIZE}

The sample sizes are 200 .

\subsection{SAMPLE AREAS}

The sample area is Chennai city.

\subsection{TOOLS OF DATA COLLECTION:}

- Questionnaire method

- Interview schedule

\subsection{QUESTIONNAIRE DESIGN:}

- Multi-point rating

- $\quad$ Open and Closed ended questions

\section{STATISTICAL TECHNIQUES:}

This phase consists of the data analysis of the data collected based on the convenient sampling technique. The data collected were analyzed using the following methods:

\subsection{PERCENTAGE ANALYSIS:}

Simple percentage analysis refers to a special kind of ratio in making comparison between two or more data and to describe relations between the data. Percentage can also be used to compare the relative terms, the distribution of two or more series of data.

$$
\begin{aligned}
& \text { No. Of respondents } \\
& \text { Total no. of respondents }
\end{aligned}
$$

\subsection{CHI-SQUARE TEST:}

A chi-square test is statistical test commonly used for the testing independence and goodness of fit. Testing independence determines whether two or more observations across two populations are dependent on each other. Testing for goodness of fit determines if an observed frequency distribution matches a theoretical frequency distribution.

In probability theory and statistics, the Chi-Square distribution with the degrees of freedom is the distribution o a sum of squares of independent standard normal random variables. It is one of the most widely used probability distribution in inferential statistics,

\section{FORMULA:}

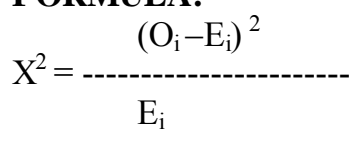

$$
\begin{aligned}
& \mathrm{X}^{2}=\text { Chi-Square, } \\
& \mathrm{O}_{\mathrm{i}}=\text { Observed frequency, } \\
& \mathrm{E}_{\mathrm{i}}=\text { Expected frequency }
\end{aligned}
$$

\subsection{BRANDS OF BATHING SOAP}

\begin{tabular}{|c|c|c|c|}
\hline S.NO & PARTCULARS & $\begin{array}{c}\text { NO OF } \\
\text { RESPONSES }\end{array}$ & $\begin{array}{c}\text { \% } \\
\text { RESPONSES }\end{array}$ \\
\hline 1 & DOVE & 62 & 31 \\
\hline 2 & VIVEL & 44 & 22 \\
\hline 3 & POWER & 36 & 18 \\
\hline 4 & INDULEKHA & 34 & 17 \\
\hline 5 & MYSORE & 24 & 12 \\
& SANDAL & & $\mathbf{1 0 0}$ \\
\hline $\mathbf{6}$ & TOTAL & $\mathbf{2 0 0}$ & \\
\hline
\end{tabular}

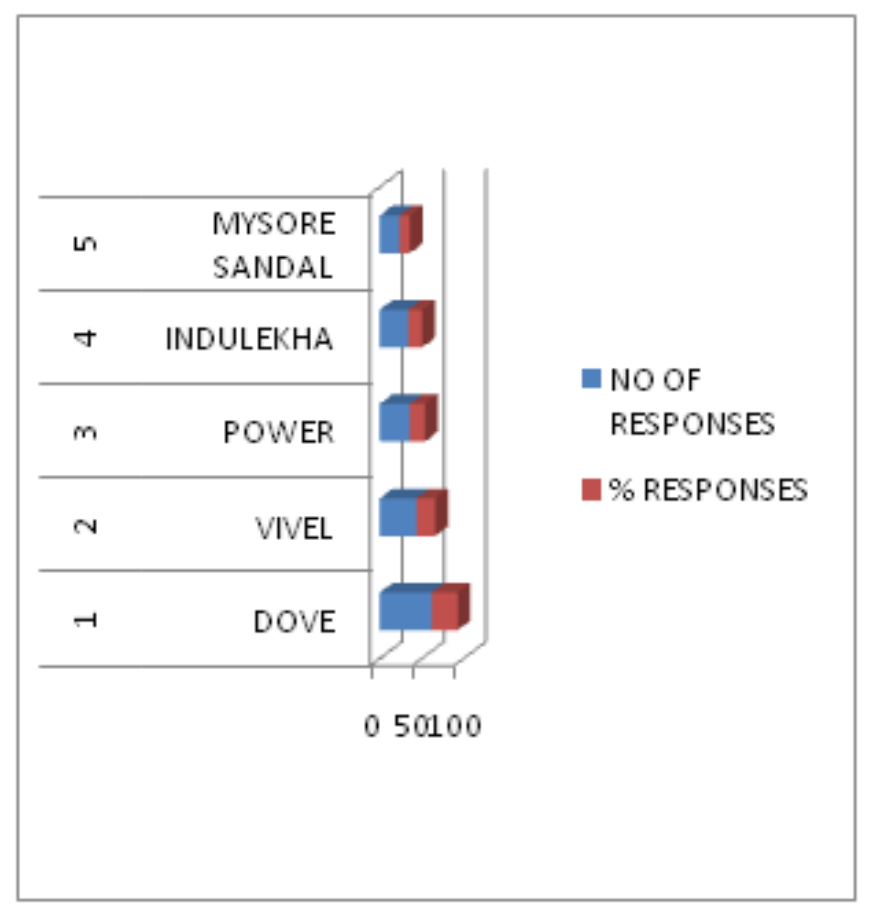

\section{INTREPRETATION}

We inferred from the table, $31 \%$ of the responses have Dove bathing soap, $22 \%$ of the responses have Vivel brand, $18 \%$ of responses have Power brand, $17 \%$ of responses have Indulekha brand and another $12 \%$ have Mysore sandal brand.

\subsubsection{RATING OF DELIVERY OF BATHING SOAP}

\begin{tabular}{|c|c|c|c|}
\hline S.NO & PARTCULARS & $\begin{array}{c}\text { NO OF } \\
\text { RESPONSES }\end{array}$ & $\begin{array}{c}\text { \% } \\
\text { RESPONSES }\end{array}$ \\
\hline 1 & $\begin{array}{c}\text { HIGHLY } \\
\text { SATISFIED }\end{array}$ & 68 & 34 \\
\hline 2 & SATISFIED & 60 & 30 \\
\hline 3 & NEUTRAL & 42 & 21 \\
\hline 4 & DISATISFIED & 30 & 15 \\
\hline 5 & $\begin{array}{c}\text { HIGHLY } \\
\text { DISATISFIED }\end{array}$ & 0 & 0 \\
\hline $\mathbf{6}$ & TOTAL & $\mathbf{2 0 0}$ & $\mathbf{1 0 0}$ \\
\hline
\end{tabular}




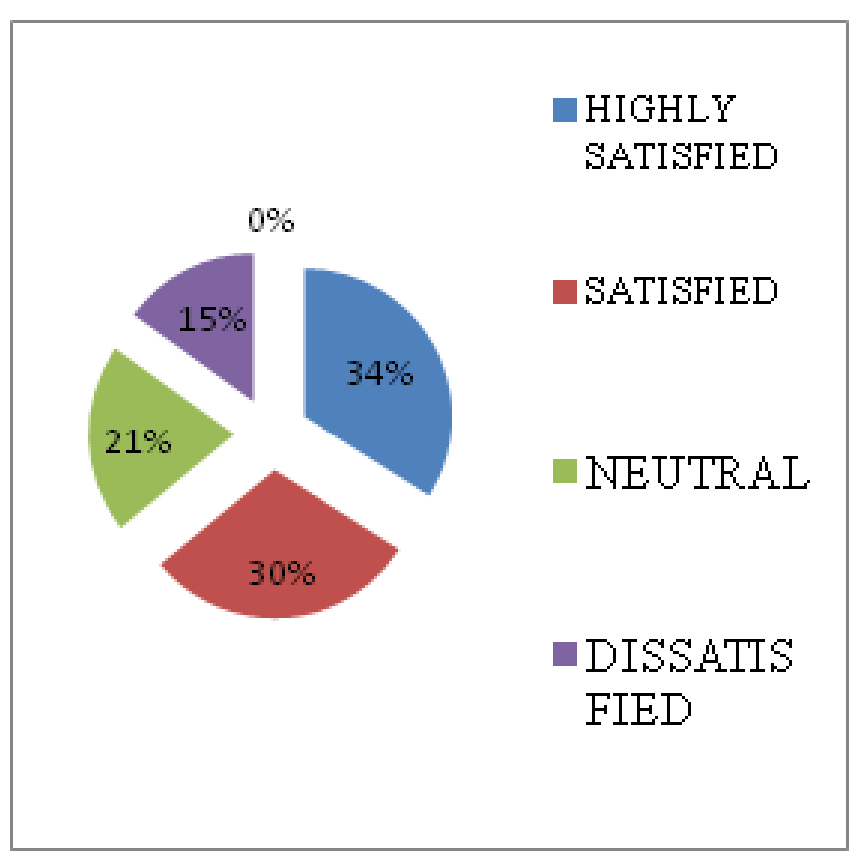

\section{INTREPRETATION}

We inferred from the table, $34 \%$ of the responses belong to category of highly satisfied parameter, $30 \%$ of the responses belong to category satisfied, $21 \%$ of the responses belong to category neutral and another $15 \%$ of the responses belong to category dissatisfied.

\subsubsection{PROMOTIONAL ACTIVITIES}

\begin{tabular}{|c|c|c|c|}
\hline S.NO & PARTCULARS & $\begin{array}{c}\text { NO OF } \\
\text { RESPONSES }\end{array}$ & $\begin{array}{c}\text { \% } \\
\text { RESPONSES }\end{array}$ \\
\hline 1 & $\begin{array}{c}\text { TELEVISION } \\
\text { AD }\end{array}$ & 68 & 34 \\
\hline 2 & POSTERS AD & 42 & 21 \\
\hline 3 & $\begin{array}{c}\text { NAME } \\
\text { BOARDS AD }\end{array}$ & 40 & 20 \\
\hline 4 & STICKERS AD & 32 & 16 \\
\hline 5 & PAMPLETS AD & 18 & 9 \\
\hline $\mathbf{6}$ & TOTAL & $\mathbf{2 0 0}$ & $\mathbf{1 0 0}$ \\
\hline
\end{tabular}

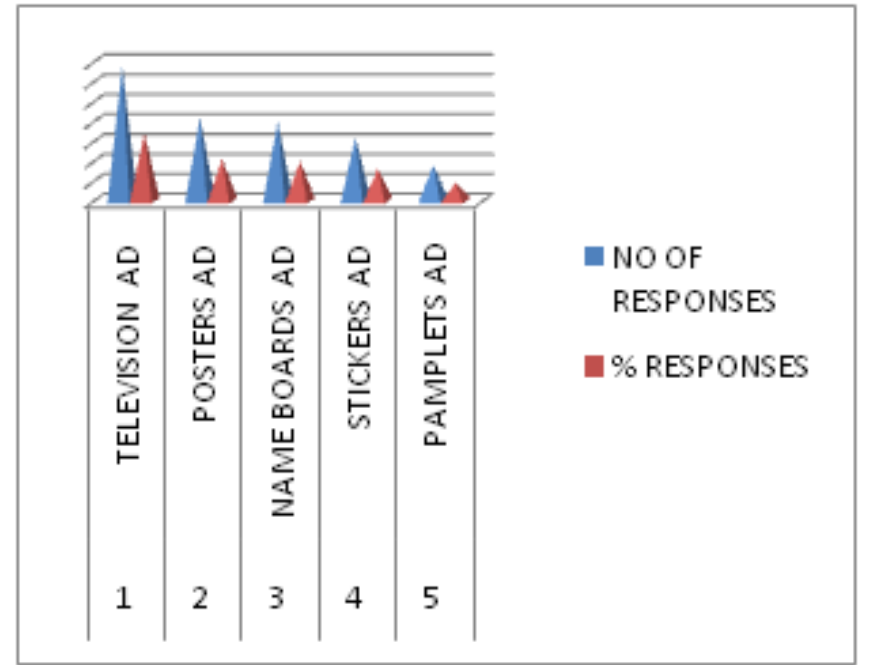

\section{INTREPRETATION}

We inferred from the table, $34 \%$ of the responses believed that Television ad were important, $21 \%$ of the responses believed that poster ads were important, $20 \%$ of the responses believed that name boards ad were important, $16 \%$ of the responses believed that stickers ad were important and another 9\% believed that pamphlets ad are important

\section{Statistical research in Result:}

\subsection{CHI-SQUARE TEST}

REGION WISE RESPONDENTS AND LEVEL OF SATISFACTION OF BRANDED BATHING SOAP Aim:

To determine the relationship between region-wise respondents and the level of satisfaction of branded bathing soap.

\section{Null Hypothesis $\left(\mathbf{H}_{0}\right)$ :}

There is no significant association between the region-wise respondents and level of satisfaction of branded bathing soap.

\section{Alternative Hypothesis $\left(\mathrm{H}_{1}\right)$ :}

There is a significant association between the region-wise respondents and level of satisfaction of branded bathing soap.

\begin{tabular}{|c|c|c|c|c|c|c|c|}
\hline \multirow[t]{2}{*}{$\begin{array}{l}\text { S. } \\
\text { No }\end{array}$} & \multirow[t]{2}{*}{$\begin{array}{l}\text { Regi } \\
\text { on }\end{array}$} & \multicolumn{5}{|c|}{$\begin{array}{c}\text { Level of Satisfaction of B randed } \\
\text { bathing soap }\end{array}$} & \multirow[t]{2}{*}{$\begin{array}{l}\text { To } \\
\text { tal }\end{array}$} \\
\hline & & $\begin{array}{c}\text { High } \\
\text { ly } \\
\text { Satis } \\
\text { fied }\end{array}$ & $\begin{array}{l}\text { Satis } \\
\text { fied }\end{array}$ & $\begin{array}{c}\mathrm{Neu} \\
\text { tral }\end{array}$ & $\begin{array}{c}\text { Disposa } \\
\text { tisfied }\end{array}$ & $\begin{array}{c}\text { Highly } \\
\text { Dissati } \\
\text { sfied }\end{array}$ & \\
\hline 1 & $\begin{array}{c}\text { Nort } \\
\mathrm{h} \\
\text { Che } \\
\text { nnai }\end{array}$ & 5 & 6 & 7 & 3 & 1 & 22 \\
\hline 2 & $\begin{array}{c}\text { Sout } \\
\mathrm{h} \\
\text { Che } \\
\text { nnai }\end{array}$ & 9 & 10 & 10 & 7 & 2 & 38 \\
\hline
\end{tabular}




\begin{tabular}{|c|c|c|c|c|c|c|c|}
3 & $\begin{array}{c}\text { East } \\
\text { Che } \\
\text { nnai }\end{array}$ & 15 & 9 & 6 & 5 & 1 & $\mathbf{3 6}$ \\
\hline 4 & $\begin{array}{c}\text { Wes } \\
\mathrm{t} \\
\text { Che } \\
\text { nnai }\end{array}$ & 17 & 13 & 8 & 6 & 0 & $\mathbf{4 4}$ \\
\hline 5 & $\begin{array}{c}\text { Cent } \\
\text { ral } \\
\text { Che } \\
\text { nnai }\end{array}$ & 12 & 14 & 11 & 19 & 4 & $\mathbf{6 0}$ \\
\hline $\begin{array}{c}\text { Tota } \\
\mathbf{l}\end{array}$ & $\mathbf{5 8}$ & $\mathbf{5 2}$ & $\mathbf{4 2}$ & $\mathbf{4 0}$ & $\mathbf{8}$ & $\mathbf{2 0}$ \\
\hline
\end{tabular}

\section{RESULT OF CHI-SQUARE TEST:}

\begin{tabular}{|c|c|c|c|c|}
\hline $\mathbf{O}_{\mathbf{i}}$ & $\mathbf{E}_{\mathbf{i}}$ & $\mathbf{O}_{\mathbf{i}}-\mathbf{E}_{\mathbf{i}}$ & $\left(\mathbf{O}_{\mathbf{i}}-\mathbf{E}_{\mathbf{i}}\right)^{2}$ & $\left(\mathbf{O}_{\mathbf{i}}-\mathbf{E}_{\mathbf{i}}\right)^{2}$ \\
\cline { 4 - 5 } & & & & $\mathbf{E}_{\mathbf{i}}$ \\
\hline 5 & 6.38 & -1.38 & 1.9044 & 0.2985 \\
\hline 6 & 5.72 & 0.28 & 0.0784 & 0.0137 \\
\hline 7 & 4.62 & 2.38 & 5.6644 & 1.2261 \\
\hline 3 & 4.4 & -1.4 & 1.96 & 0.4455 \\
\hline 1 & 0.88 & 0.12 & 0.0144 & 0.0164 \\
\hline 9 & 11.02 & -2.02 & 4.0804 & 0.3703 \\
\hline 10 & 9.88 & 0.12 & 0.0144 & 0.0015 \\
\hline 10 & 7.98 & 2.02 & 4.0804 & 0.5113 \\
\hline 7 & 7.6 & -0.6 & 0.36 & 0.0474 \\
\hline 2 & 1.52 & 0.48 & 0.2304 & 0.1516 \\
\hline 15 & 10.44 & 4.56 & 20.7936 & 1.9917 \\
\hline 9 & 9.36 & -0.36 & 0.1296 & 0.0138 \\
\hline 6 & 7.56 & -1.56 & 2.4336 & 0.3219 \\
\hline 5 & 7.2 & -2.2 & 4.84 & 0.6722 \\
\hline 1 & 1.44 & -0.44 & 0.1936 & 0.1344 \\
\hline 17 & 12.76 & 4.24 & 17.9776 & 1.4089 \\
\hline 13 & 11.44 & 1.56 & 2.4336 & 0.2127 \\
\hline 8 & 9.24 & -1.24 & 1.5376 & 0.1664 \\
\hline 6 & 8.8 & -2.8 & 7.84 & 0.8909 \\
\hline 12 & 17.4 & -5.4 & 29.16 & 1.6759 \\
\hline 14 & 15.6 & -1.6 & 2.56 & 0.1641 \\
\hline 11 & 12.6 & -1.6 & 2.56 & 0.2032 \\
\hline 19 & 12 & 7 & 49 & 4.0833 \\
\hline 4 & 2.4 & 1.6 & 2.56 & 1.0667 \\
\hline \multicolumn{5}{|c|}{ Total } \\
\hline
\end{tabular}

$\chi^{2}=\Sigma=16.0883$

$\mathrm{E}_{\mathrm{i}}$

Degrees of freedom $=(\mathrm{r}-1)(\mathrm{c}-1)$

$=(5-1)(5-1)$

$=16$

Calculated value of chi-square $=16.0883$

Table value at $5 \%$ level with 16 degrees of freedom $=26.29$

As calculated chi-square (16.0883) is less than the table value

(26.29). The Null hypothesis is accepted.

\section{INTERPRETATION:}

Table value of $\mathrm{X}$ for degree of freedom $=16$ and at $5 \%$ level of significance $=26.29$. Now let us compare the table value of $X$ [26.29], with in the computed value of $X^{2}=16.0883$. Since the table value is greater the calculated value. So the null hypothesis is accepted.

\section{INFERENCE:}

Hence, it is concluded that there is no significant association between the region-wise the respondents and level of satisfaction with the branded bathing soap.

\section{REFERENCE AND CONCLUSION}

In this competitive world, every company has to make valuable decision for profit maximisation through sales maximisation. Even though soap industry, product and service differentiation only highlights the company from the competitors than only it able get more success. The project identifies the market potential of new product development in branded bathing soap in Chennai City. It also provides some strategies to increase retailer and consumer preference on branded bathing soap. The organisation should ensure that its systems like quality, performance, service and compliant redressal are designed to achieve excellence and customer delight.

Every person and organization has some responsibilities to their nation and their country. Having these responsibilities in mind, we have identified the problems that may be the one of the major cause of concern for this sector of business. By working on the suggestions provided by the study, any branded bathing soap company can place a dominant position in the market as well as in the minds of the customers.

\section{Reference:}

1. Compell, T.1999 Black in focus sales in marketing management 151(2):56-61

2. Walter, rockney (1991),"Assessing the impact of retail price promotion on product substitutions, complimentary purchase, and inters tore sale displacement:"journals of marketing, Vol.55,No. 2(April), 17-28

3. Booz, allen \& Hamilton (1968), Management of new product, New York: Booz, Allen \&Hamilton

4. Business research method" Alan Bryman,'Emma bell oxford university press U.K $4^{\text {th }}$ Edition 